\title{
KIT NM_000222.2:C.2554G>A
}

National Cancer Institute

\section{Source}

National Cancer Institute. KIT NM 000222.2:C.2554G>A. NCI Thesaurus. Code C155720.

A nucleotide substitution at position 2554 of the coding sequence of the KIT gene where guanine has been mutated to adenine. 